\title{
A Study of the Relationship between Test Anxiety and Study Habits of Physical Education Students
}

\author{
Dr Mohammad Ahsan \\ Assistant Professor, College of Applied Medical Science, University of Dammam, Dammam KSA \\ DrAnand Kumar
}

Assistant Professor, Deptt.of Education, Shri Guru Ram Rai (PG) College, Dehradun, Uttarakhand, India

\begin{abstract}
This study was undertaken to study the relationship between test anxiety and study habits of physical education male and female students. The method used for the study was correlation design. The sample consisted of 166 (83 male +83 female) physical education students. The sample has been selected on the basis of random sampling technique. Prof Ms. AnupSud \& PrernaSud's Test Anxiety Inventory (TAI- H) and Dr. B.V. Patel's Study habits inventory has been used for the data collection. The students read all the directions silently and carefully before they put any answer or responses as mention on the test form. They also provide their demographic details as required. Students fill both inventories within given time. The test was conducted in class room environment. For analyzing and interpreting the, data the percentile analysis and Pearson's product moment correlation were used to determine the significance relationship between test anxiety and study habits of physical education students. The result of the study highlights that there is a negative correlation between study habits and test anxiety; we can say that the academic performance will get affected negatively because of high level of test anxiety and poor study habits.
\end{abstract}

Keywords: Test anxiety, study habits, physical education, correlation.

\section{INTRODUCTION}

The test anxiety plays an important role for students to sustain the efficacy and usefulness of learning performance. Sansgiry and Sail (2006) defined test anxiety as the "reaction to stimuli that are associated with an individual's experience of testing or evaluative situations". Test anxiety is the mental distress and fear experienced by students when they have to face examinations of any type (or) any of its related activities. Jerri Wine (1971) suggests that the performance difference between high and low test-anxious persons is due to loss of attentional focus during the task being performed. Zeidner (1998) suggested that many children in their own culture became test-oriented and test anxious. Putwain (2008) stated that test anxiety appeared in specific situation or environment in which performance was assessed. Campos et al. (2004) suggested that anxiety was considered as one of the major factors causing students to go down below their actual performance. Culler and Holahan (1980) replicated the finding of past researches had shown that test anxiety is closely related with significant decrease in academic performance.

Study means to supply one's mental capacities to the acquisition of knowledge. Students of any grade level can have difficulty in school due to a lack of sufficient study skills (Gettinger \&Seibert, 2002). Habit is something that is done and on a scheduled, regular and planned basis that it not regulated to a second place or optional place in one's life. There is no doubt that study habits can be improved step by step. Study habits are very easy to improve and habits are very important for the acquisition of knowledge. Even the most intelligent student cannot show their best if they do not possess sound study habits. Kholi (1977) pointed out that in the academic field, study habits are of particular theoretical and practical importance. Researches suggests that poor study habits are problem areas for some students which can lead to an increase in anxiety (Zeidner, 1998; Sweidel, 1996; Gettinger\& Seibert, 2002; Britton \&Tesser, 1991).Some studies have found that time management, as well as poor study habits, is one of the leading correlates of low academic performance (Sweidel, 1996). 
Students are affected from various factors to develop good study habits. As we know that in the present era the current generation is busy most of the times with the electronic gadgets and they are least interested in their studies. The basic cause of failure in examination is that either the students do not have effective study skills or they have poor study habits (Turkcan \& Ocal, 2003). Educational institutions should try to understand various factors affecting the students in specific areas from time to time and should become the integral part of their achievement, progression and development. This leads the researcher to conduct this study to distinguish the relationship between test anxiety and study habits of senior secondary school students.

\section{MeTHODS}

\section{Research Design}

This study adopted descriptive correlation survey design methods. It involves correlation to discover the relationship between existing non-manipulating variables.

\section{Sample}

The sample size comprises of 166 physical education students, selected by simple random sampling technique. There are 83 male and 83 female studying in senior secondary school.

Table1

\begin{tabular}{|c|c|}
\hline Type of Gender & Number of Students \\
\hline Male & $83(50 \%)$ \\
\hline Female & $83(50 \%)$ \\
\hline Total & $166(100 \%)$ \\
\hline
\end{tabular}

\section{Research Tools}

Test Anxiety Inventory (TAI- H) of Prof Ms. AnupSud \& PrernaSud was used for the study to measure test anxiety. It consists of two subscales for measuring "Worry" and "Emotionality" having eight items in each subscale. The range of possible scores for this instrument varies from a minimum score of 20 to maximum score of 80 . The subject responds to each item by rating himself on a fourpoint rating scale, ranging from: 1) almost never to (2) sometimes, (3) often and (4) almost always.

Study habits inventory constructed and standardized by Dr. B.V. Patel has been used for the study to measure study habits. The test consists of 45 items and each statement based on five-point scale (1. Always, 2. Often, 3. Sometimes, 4. Hardly, 5.Never). The maximum possible score on the inventory would be 225 and the least possible score would be 45 .

\section{Administration of Tools}

All the instructions were given on each test form. The students read the directions silently and carefully before they put any answer or responses. Researcher instructs to respond to all of the items. They also have to fill their demographic details (names, gender, school types, location etc.,) as required. Students fill all inventories with in fifty-five minutes' time span.

\section{Statistical Design}

For analyzing and interpreting the data the investigator used Microsoft excel 2010 to percentile analysis and Pearson's product moment correlation to measure the significance relationship between test anxiety and study habits of physical education students studying in senior secondary schools.

\section{RESULTS}

Table2. Distribution of Physical Education Students on the Basis of Gender and Test Anxiety for the Total Sample

\begin{tabular}{|c|c|c|c|c|}
\hline \multirow[t]{2}{*}{ Gender } & \multicolumn{4}{|c|}{ Level of Test Anxiety } \\
\hline & Low & Average & High & Total \\
\hline \multirow[t]{2}{*}{ Male } & 17 & 51 & 15 & 83 \\
\hline & $(10.24 \%)$ & $(30.73 \%)$ & $(9.04 \%)$ & $(50 \%)$ \\
\hline \multirow[t]{2}{*}{ Female } & 04 & 59 & 20 & 83 \\
\hline & $(2.41 \%)$ & $(35.54 \%)$ & $(12.04 \%)$ & $(50 \%)$ \\
\hline \multirow[t]{2}{*}{ G. Total } & 21 & 110 & 35 & 166 \\
\hline & $(12.65 \%)$ & $(66.27 \%)$ & $(21.08 \%)$ & $(100 \%)$ \\
\hline
\end{tabular}


From the above table it has been concluded that $10.24 \%$ males have low level of test anxiety, $30.73 \%$ have reported average level of test anxiety while $9.04 \%$ have experienced high level of test anxiety. In the same way, $2.41 \%$ females have reported low level of test anxiety, $35.54 \%$ have an average level of test anxiety and the remaining $12.04 \%$ have reported high level of test anxiety.

Table3. Distribution of Physical Education Students on the Basis of Gender and Study Habits for the Total Sample

\begin{tabular}{|l|l|l|l|l|}
\hline \multirow{2}{*}{ Gender } & \multicolumn{4}{|l|}{ Grading of study habits } \\
\cline { 2 - 5 } & Poor & Normal & Good & Total \\
\hline \multirow{2}{*}{ Male } & 14 & 57 & 12 & 83 \\
\cline { 2 - 5 } & $(8.43 \%)$ & $(34.34 \%)$ & $(7.23 \%)$ & $(50 \%)$ \\
\hline \multirow{3}{*}{ Gemale } & 11 & 56 & 16 & 83 \\
\cline { 2 - 5 } & $(6.63 \%)$ & $(33.73 \%)$ & $(9.64 \%)$ & $(50 \%)$ \\
\cline { 2 - 5 } & $\mathbf{2 5}$ & $\mathbf{1 1 3}$ & $\mathbf{2 8}$ & $\mathbf{1 6 6}$ \\
\cline { 2 - 5 } & $\mathbf{( 1 5 . 0 6 \% )}$ & $\mathbf{( 6 8 . 0 7 \% )}$ & $\mathbf{( 1 6 . 8 7 \% )}$ & $\mathbf{( 1 0 0 \% )}$ \\
\hline
\end{tabular}

It is evident from the above table that $8.43 \%$ male studying at senior secondary level have reported poor study habits, $34.34 \%$ have normal study habits and $7.23 \%$ have good study habits. Similarly, $6.63 \%$ females studying at senior secondary level have reported poor study habits, $33.73 \%$ have normal study habits while the remaining $9.64 \%$ have reported good study habits.

Table4. Relationship between Study Habits and Test Anxiety of Male Physical Education Students

\begin{tabular}{|l|l|l|l|}
\hline $\mathbf{N}=\mathbf{8 3}$ & \multicolumn{2}{|l|}{} \\
\hline S. No. & Variables & 'r' value & Level of significance \\
\hline 1. & Study habits & -0.44 & $\begin{array}{l}\text { Significant } \\
\text { at } 0.01 \text { level }\end{array}$ \\
\hline 2. & Test anxiety & & \\
\hline
\end{tabular}

Observation of the table -4reveals that 'r' value between the study habits and test anxiety of the male physical education students is negative and statistically significant at 0.01 level. Thus, it may be inferred that the study habits and test anxiety of the male physical education students have negative correlation i.e. as the scores on test anxiety scale decreases, the scores on study habits inventory will increase and it can be said that good study habits among the male physical education students leads to low level of test anxiety.

Table5. Relationship between the study habits and test anxiety of female Physical education students

\begin{tabular}{|l|l|l|l|}
\hline $\mathbf{N}=\mathbf{8 3}$ & 'r' value & Level of significance \\
\hline S. No. & Variables & 'r' & $\begin{array}{l}\text { Significant } \\
\text { at } 0.01 \text { level }\end{array}$ \\
\hline 1. & Study habits & -0.32 & Test Anxiety \\
\hline 2. & &
\end{tabular}

Observation of the table - 5 reveals that ' $r$ ' value between the study habits and test anxiety of the female physical education students is negative and statistically significant at 0.01 level. Thus, it may be inferred that the study habits and test anxiety of the female physical education students have negative correlation i.e. as the scores on test anxiety scale decreases, the scores on study habits inventory will increase and it can be said that good study habits among the female physical education students leads to low level of test anxiety.

\section{DisCussion}

The researcher studied the relationship between the study habits and test anxiety of the physical education students studying at senior secondary level. The findings of the study revealed that there is negative relationship between the study habits and test anxiety of male and female physical education students studying at senior secondary level. The ' $r$ ' value between the study habits and test anxiety of the male physical education students is found to be negative but statistically significant 0.01 level. In the same way the ' $r$ ' value between the study habits and test anxiety of the female physical education students is also found to be negative but statistically significant at 0.01 level. Thus, it can be inferred that male and female physical education students having good study habits have low level of test anxiety. These findings are supported by the findings of Lawrence A. (2014) shows that there is no significant difference between higher secondary school boys and girls in their study habits and test anxiety. The researcher found that the test anxiety of girls was higher than the boys. The findings of the study support the findings of Devine et al. (2012), Baskar (2012), Surjit Singh (2010) and Mark Chapell (2005). 
As the study revealed that there is a negative correlation between study habits and test anxiety, we can say that the academic performance will get affected negatively because of high level of test anxiety and poor study habits. We can observe that the teenagers of present generation are more active with social media sites and the use of various electronic gadgets leading to poor study habits because of poor time management and when they encounter any evaluative situation their test anxiety level becomes higher as they also experience a high pressure from parents and society to perform better. Finally, this condition may lead to the state of depression as these youths are unable to fulfill the desire of their parents and the society. Hence, this can be concluded that proper guidance and counseling facility should be available to the students, so that they can manage their time as well as energy in a proper way, to develop better study habits and to control their level of test anxiety.

\section{CONCLuSION}

From the above study the researchers have come on the conclusion that the level of test anxiety and study habits of the physical education students is moderate. Therefore there is a need for the improvement of the study habits of students so that can study effectively and improve their academic performance. It is much important to engage students in a better organized teaching and guidance process to improve their study habits.

\section{REFERENCES}

Baskar, M. (2012). Study involvement and test anxiety of higher secondary students. An unpublished M.Ed. dissertation submitted to Tamil Nadu Teachers Education University, Chennai.

Britton, B. K. \&Tesser, A. (1991).Effects of time-management practices on college grades. Journal of Educational Psychology, 83, 406-410.

Campos, B., Keltner, D., Tapias, M. P. (2004). Emotion, Charles D. Speilberger (Ed.) In Encyclopedia of Applied Psychology.(1. Bask1). Elsevier Academic Press.

Chapell, S. Mark et al. (2005). Test anxiety and academic performance in undergraduate and graduate students. Journal of Educational Psychology, 97(2): 268-274. doi: 10.1037/0022-0663.97.2.268

Culler, R. E. \&Holahan, C. J. (1980). Test anxiety and academic performance: The effects of studyrelated behaviors. Journal of Educational Psychology, 72, 16-20.

Devine, et al. (2012). Gender differences in mathematics anxiety and the relation to mathematics performance while controlling for test anxiety. Behavioral and Brain Functions, 8(33): 1-9. Retrieved from http://www.biomedcentral.com/content/pdf/1744-9081-8-33.pdf

Gettinger, M. \& Seibert, J. K. (2002) Contributions of study skills to academic competence. School Psychology Review, 31, 350-365

Jerri Wine, (1971). Test Anxiety and direction of attention. Psychological Bulletin, 76, 92-104.

Kohli, A. (1977). The importance of Study Habits and how to Enhance Individual Learning? The Educational Reforms. Cambridge University Press

Lawrence A. (2014).Relationship between study habit and test anxiety of higher secondary students. International journal of teacher educational research $3(6): 1-9$

Putwain, D. W. (2008): Deconstructing test anxiety. Emotional and Behavioural Difficulties, 13(2), 141-155. DOI: 10.1080/13632750802027713.

Sansgiry, S. S. \& Sail, K. (2006).Effect of students' perceptions of course load on test anxiety. American Journal of Pharmaceutical Education, 70, 1-6

Singh, Surjit (2010). Relationship of anxiety and emotional and social maturity with actualization of general mental ability of high school students. An published Ph.D. dissertation submitted to Guru Nanak Dev University. Retrieved from http://hdl.handle.net/10603/7062

Sweidel, G. B. (1996). Study strategy portfolio: A project to enhance study skills and time management. Teaching of Psychology, 23, 246-248.

Türkcan, G., \&Öcal, G. (2003).Verimlidersçalışmateknikleri.ÇolukÇocuk, 31, $26-27$.

Zeidner, M. (1998). Test Anxiety, The State of the Art. New York: Plenum. 